\title{
$N$-Phenacylthiazolium Salts as Inhibitors of Cholinesterases
}

\author{
Alla D. Ocheretniuk, Oleksandr L. Kobzar, Iryna M. Mischenko, Andriy I. Vovk* \\ Institute of Bioorganic Chemistry and Petrochemistry of the National Academy of Sciences \\ of Ukraine, Murmanska Street, 1, Kyiv-94 02094, Ukraine \\ vovk@bpci.kiev.ua
}

Keywords: acetylcholinesterase, butyrylcholinesterase, thiamin, N-phenacylthiazolium salts, inhibition

Inhibition of acetylcholinesterase is considered as a promising approach for treatment of neurodegenerative disorders including Alzheimer's disease. In this study, we demonstrated that 5substituted $\mathrm{N}$-phenacylthiazolium derivatives are capable of inhibiting acetylcholinesterase and butyrylcholinesterase activities with $\mathrm{IC}_{50}$ values in the micromolar range. Some of the new thiazolium-based inhibitiors showed more than 10-fold selectivity for butyrylcholinesterase. Kinetic experiments and molecular docking were performed for understanding the inhibition mechanisms.

\section{Introduction}

Acetylcholinesterase (AChE) and butyrylcholinesterase (BChE) belong to a class of serine hydrolases and have $65 \%$ identity in amino acid sequences $[1,2]$. The function of $\mathrm{AChE}$ is termination of nerve impulses at the cholinergic synapses through acetylcholine hydrolysis. Reduced amount of the acetylcholine, because of abnormal activity of choline acetyltransferase [3, 4], along with extracellular deposits of $\beta$-amyloid in senile plaques is associated with cognitive function impairment in patients with Alzheimer's disease $[5,6]$. According to the cholinergic hypothesis [7], consequences of the neurotransmitter deficit can be reduced by inhibition of AChE [5, 8]. Such approach is used in treatment of Alzheimer's disease and may be effective in
Parkinson's disease and dementia with Lewy bodies [9-11]. The functions of $\mathrm{BChE}$ are still not fully understood. This enzyme is able to participate in fat metabolism [12], protect the AChE from inactivation by the anticholinergic agents [13], and compensate the lack of AChE activity $[14,15]$. In addition, $\mathrm{BChE}$ is involved in the formation of amyloid plaques [16], and increased activity of the enzyme is observed in Alzheimer's disease [1, 17, 18].

$$
\text { 2,4-Substituted thiazoles }
$$

including thiazole drug acotiamide [22] as well as derivatives of benzothiazole, [23, 24] thiazolopyrimidine, [25] and thiazolotriazinone $[26,27]$ can exhibit inhibitory properties against AChE and BChE. It should be noted that some of thiazolium salts may be considered as neuromuscular blocking agents [28, 29]. 
Thiamine pyrophosphate and thiazolium salts were shown to break protein crosslinks (AGEs) [30-32]. Vitamin $\mathrm{B}_{1}$ (thiamine) and its derivatives are important regulators of metabolic processes in the central nervous system [33, 34] possessing a weak inhibitory action on cholinesterases [35].

We have suggested that the thiazolium scaffold may be used to design compounds with enhanced inhibitory potential against cholinesterases. In this paper, a series of $N$ phenacyl-4-methyl-5-(2-substituted) thiazolium salts has been synthesized and tested for their ability of inhibiting acetylcholinesterase and butyrylcholinesterase in vitro.

\section{Results and discussion}

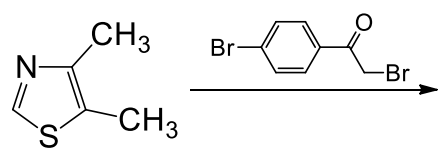

1
Chemistry

Target $N$-phenacylthiazolium salts $\quad \mathbf{5 - 1 7}$ were obtained in two steps (Scheme 1). The synthetic procedure involves the preparation of compounds 4a-i by reaction of 5-(2hydroxyethyl)-4-methyl-1,3-thiazole (3) with the appropriate acyl chlorides [36-38]. Then, the $O$-acylated compounds were reacted with corresponding phenacyl bromides, giving thiazolium salts 5-17. Compound 2 was synthesized by quaternization of 4,5-dimethyl1,3-thiazole (1) [32].

\section{Inhibitory activity}

The activities of the thiazolium salts were evaluated in vitro using $\mathrm{AChE}$ from $E$. electricus and $\mathrm{BChE}$ from equine serum. The<smiles>Cc1sc[n+](CC(=O)c2ccc(Br)cc2)c1C</smiles>

2<smiles>[R]C(=O)OCCc1sc[n+](CC(=O)c2ccc([R])cc2)c1C</smiles>

$\mathrm{R}^{1}$ :

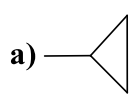

b)<smiles>Clc1ccccc1</smiles><smiles>COc1ccc(Cl)cc1</smiles><smiles>O=[N+]([O-])c1ccc(Cl)cc1</smiles>

$\mathrm{R}^{2}: \mathrm{H} ; \mathrm{Br}$<smiles>O=[N+]([O-])c1cccc(Br)c1</smiles><smiles>O=[N+]([O-])c1ccc(Cl)c(Cl)c1</smiles>

h)<smiles>Cc1ccc(N2CCOCC2)c([N+](=O)[O-])c1</smiles><smiles>IC(c1ccccc1)c1ccccc1</smiles>

Scheme 1. Synthesis of $N$-phenacylthiazolium salts 2, 5-17. 
results in Table 1 show that the nature of $\mathrm{R}^{1}$ substituent modulates inhibitory activity of the compounds tested. Thiazolium salts 2 and 5-10 exhibited weak inhibitory effects on activity of AChE, while BChE was more inhibited, especially by compounds 6-9 bearing norbornyl, phenyl or 4-methoxyphenyl groups. Among them, the highest inhibitory activity toward BChE was observed for 5-(4methoxybenzoyloxyethyl) substituted thiazolium salt $9\left(\mathrm{IC}_{50}=0.94 \mu \mathrm{M}\right)$ with more than 30-fold selectivity over AChE. 3-
Nitrophenyl derivatives $\mathbf{1 2 - 1 4}$ were found to be more potent inhibitors of both $\mathrm{AChE}$ and $\mathrm{BChE}$ as compared to their 4-nitrophenyl analogs 1011. Compound 14 exhibits $\mathrm{IC}_{50}$ of $0.85 \mu \mathrm{M}$ for $\mathrm{AChE}$ and $\mathrm{IC}_{50}$ of $1.4 \mu \mathrm{M}$ in case of $\mathrm{BChE}$. Further modification of substituent $\mathrm{R}^{1}$ with morpholino groups did not improve significantly the inhibitory properties of compounds 15 and 16. Introduction of bromine atom as $\mathrm{R}^{2}$ resulted in decreasing the inhibitory effects of compounds $\mathbf{1 0}$ and $\mathbf{1 5}$ on $\mathrm{AChE}$ whereas the inhibitory ability of compounds 7

Table 1. Compounds 2, 5-17 as inhibitors of cholinesterases ${ }^{a, b, c}$

\begin{tabular}{c|c|c|c|c}
\hline \multirow{2}{*}{ № } & \multirow{2}{*}{$\mathrm{R}^{2}$} & \multirow{2}{*}{$\mathrm{R}^{1}$} & \multicolumn{2}{|c}{$\mathrm{IC}_{50} \mu \mathrm{M}$} \\
\cline { 4 - 5 } & & - & $\mathrm{AChE}$ & $\mathrm{BChE}$ \\
\hline $\mathbf{2}$ & - & $52.0 \pm 12.8$ & $59.7 \pm 9.9$ \\
$\mathbf{5}$ & $\mathrm{Br}$ & cyclopropanyl & $59.2 \pm 14.9$ & $66.7 \pm 14.1$ \\
$\mathbf{6}$ & $\mathrm{H}$ & bicyclo[2.2.1]heptane-1-yl & $51.3 \pm 15.4$ & $4.2 \pm 0.5$ \\
$\mathbf{7}$ & $\mathrm{Br}$ & phenyl & $57.8 \pm 13.4$ & $6.7 \pm 1.2$ \\
$\mathbf{8}$ & $\mathrm{H}$ & phenyl & $44.2 \pm 6.3$ & $4.5 \pm 0.9$ \\
$\mathbf{9}$ & $\mathrm{H}$ & 4-metoxyphenyl & $33.1 \pm 7.9$ & $0.94 \pm 0.28$ \\
$\mathbf{1 0}$ & $\mathrm{Br}$ & 4-nitrophenyl & $22.0 \pm 4.9$ & $15.7 \pm 4.6$ \\
$\mathbf{1 1}$ & $\mathrm{H}$ & 4-nitrophenyl & $8.8 \pm 1.0$ & $16.3 \pm 4.7$ \\
$\mathbf{1 2}$ & $\mathrm{Br}$ & 3-nitrophenyl & $2.8 \pm 0.5$ & $2.8 \pm 0.4$ \\
$\mathbf{1 3}$ & $\mathrm{H}$ & 3-nitrophenyl & $2.7 \pm 0.6$ & $2.4 \pm 0.5$ \\
$\mathbf{1 4}$ & $\mathrm{H}$ & 2-chlor-5-nitrophenyl & $0.85 \pm 0.23$ & $1.9 \pm 0.55$ \\
$\mathbf{1 5}$ & $\mathrm{Br}$ & 4-morpholino-3-nitrophenyl & $22.9 \pm 3.7$ & $1.0 \pm 0.18$ \\
$\mathbf{1 6}$ & $\mathrm{H}$ & 4-morpholino-3-nitrophenyl & $7.7 \pm 1.2$ & $2.1 \pm 0.44$ \\
$\mathbf{1 7}$ & $\mathrm{H}$ & 2,2-diphenylmethyl & $10.4 \pm 0.99$ & $0.14 \pm 0.03$ \\
\hline
\end{tabular}

${ }^{a} \mathrm{IC}_{50}$ values are the means of 2-3 assays \pm standard deviations; ${ }^{b}$ under assay conditions the substrates concentration were $0.1 \mathrm{mM}$ and $0.5 \mathrm{mM}$ for $\mathrm{AChE}$ and $\mathrm{BChE}$, respectively; ${ }^{\mathrm{c}}$ The determined $K_{\mathrm{m}}$ values were $0.31 \mathrm{mM}(\mathrm{AChE})$ and $0.26 \mathrm{mM}$ (BChE). 
and 12 was unchanged. Among the inhibitors tested, compound 17 demonstrated the most potent $\mathrm{BChE}$ inhibition $\left(\mathrm{IC}_{50}=0.14 \mu \mathrm{M}\right)$ with more than 50-fold selectivity over $\mathrm{AChE}\left(\mathrm{IC}_{50}=\right.$ $10.4 \mu \mathrm{M})$.

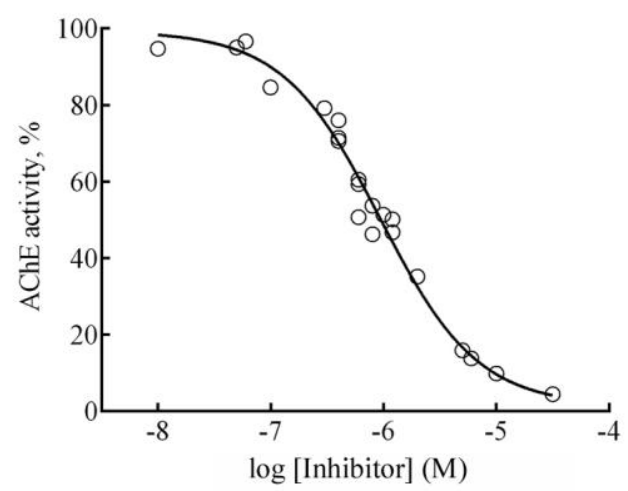

Figure 1. Dose-dependent curve of AChE inhibition by compound 14.

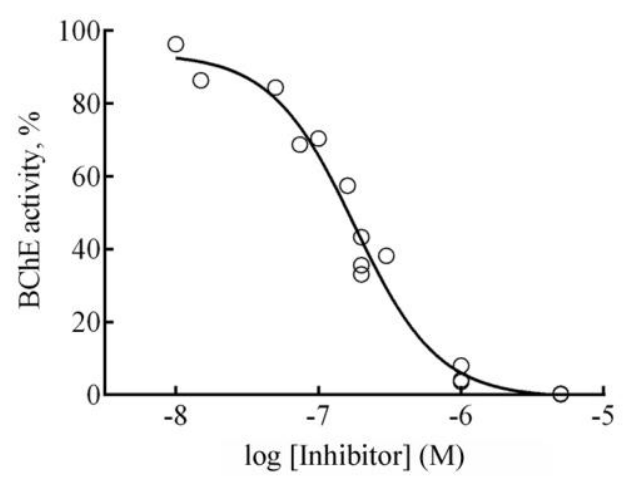

Figure 2. Dose-dependent curve of BChE inhibition by compound 17.

The dose-dependent curves of AChE and BChE inhibition by compounds 14 and 17 showed in Figures 1 and 2, respectively. The Hill coefficient for the inhibition of AChE by compound 14 is $1.01 \pm 0.13$. This suggests that only one binding site on the enzyme molecule surface may be involved in the inhibition mechanism. In case of BChE the Hill coefficient was $1.48 \pm 0.29$ indicating possibility of more than one binding site for compound $\mathbf{1 7}$.

A Lineweaver-Burk plot for inhibition of AChE by compound 14 (Figure 3) showed a mixed type mechanism. The calculated values of $K_{\mathrm{i}}$ and $K_{\mathrm{i}}^{\prime}$ are $0.78 \pm 0.09 \mu \mathrm{M}$ and $2.11 \pm 0.22$ $\mu \mathrm{M}$, respectively. According to this, the compound binds to the free enzyme and the enzyme-substrate complex. The mixed type inhibition of AChE (Scheme 2) can include interaction of the inhibitor with covalent acylenzyme intermediate, which results in block of the deacetylation step [39-41].

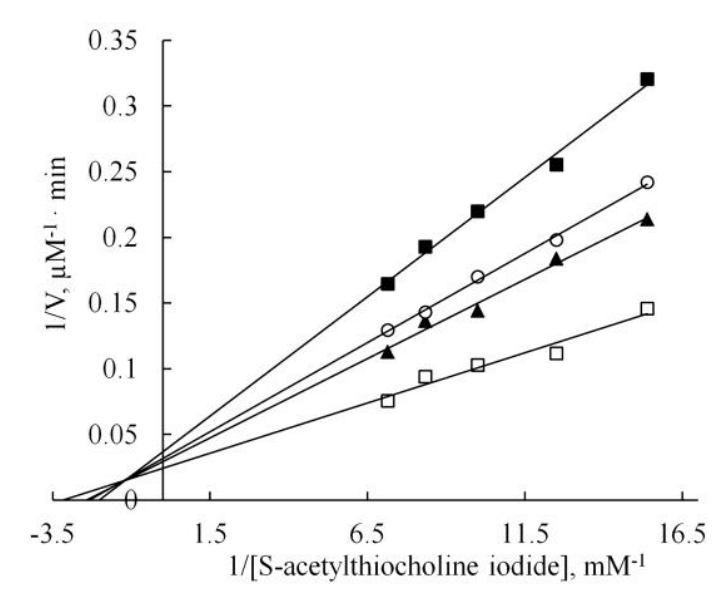

Figure 3. Lineweaver-Burk plots for inhibition of AChE by compound 14. Concentrations of the inhibitor were: $\square$ - $0, \boldsymbol{\Delta}-0.4 \mu \mathrm{M}, \circ-0.6 \mu \mathrm{M}$ and $\mathbf{\square}-1.2 \mu \mathrm{M}$.

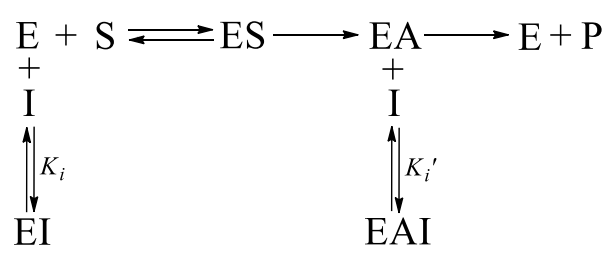

Scheme 2. Probable mechanism of AChE inhibition by compound 14. 
Regarding BChE, Lineweaver-Burk cholinesterases. Donepezil is more effective reciprocal plot (Figure 4) showed that inhibitor of AChE, with lower activity against compound $\mathbf{1 7}$ is competitive inhibitor of the $\mathrm{BChE}$ [1]. In our experiments, $\mathrm{IC}_{50}$ values of enzyme with $K_{\mathrm{i}}$ value of $0.098 \pm 0.057 \mu \mathrm{M}$. donepezil were of $0.013 \mu \mathrm{M}$ and $2.29 \mu \mathrm{M}$ for This suggests that the inhibitor is positioned in AChE and BChE, respectively. the active site, preventing the substrate binding (Scheme 3).

\section{Molecular docking}

Molecular docking calculations were

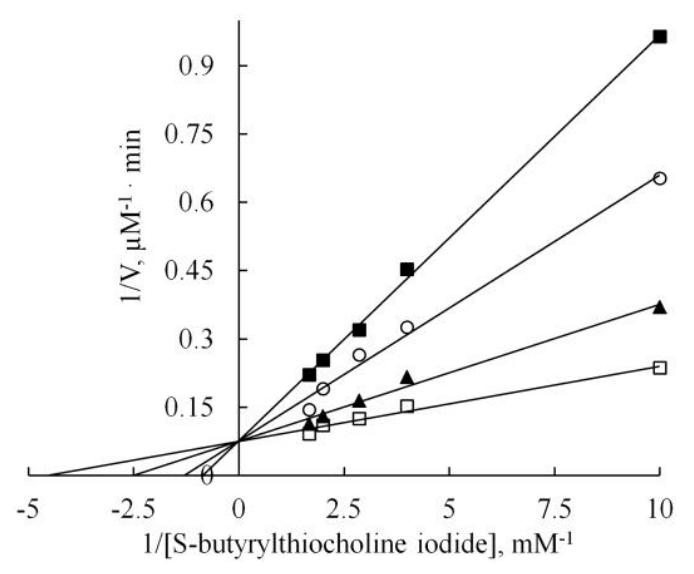

Figure 4. Lineweaver-Burk plots for inhibition of $\mathrm{BChE}$ by compound 17. Concentration of the inhibitor were: $\square$ $0, \boldsymbol{\Delta}-0.01 \mu \mathrm{M}, \circ-0.016 \mu \mathrm{M}$ and $\mathbf{\square}-0.02 \mu \mathrm{M}$.

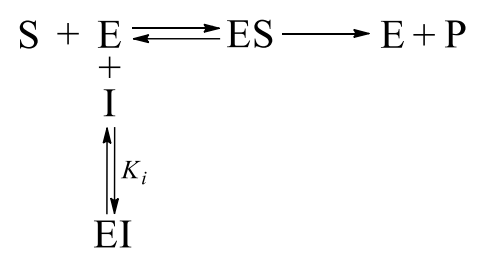

Scheme 3. Mechanism of competitive inhibition of BChE by compound 17 .

It should be noted that rivastigmine, galantamine and donepezil are widely used today in symptomatic treatment of neurodegenerative diseases [7]. Rivastigmine exhibits a dual action with inhibiting both of the carried out by using Autodock 4.2 in order to elucidate possible binding modes of the thiazolium derivatives with $\mathrm{AChE}$ and $\mathrm{BChE}$. In case of compound 14, the inhibitor occupies the gorge of active site of AChE (Figure 5) with the estimated binding energy of $-9.13 \mathrm{kcal} / \mathrm{mol}$. The inhibitor is involved in aromatic-aromatic interactions with $\operatorname{Trp} 86$ in the anionic subsite as well as Trp286 in peripheral anionic site, and Phe338 at acyl binding pocket, which is consistent with the known mechanisms of AChE inhibition [42]. The oxygen atom of carbonyl group participates in hydrogen bonds with NH-groups of backbone chains of Phe295 and Arg296. The $\mathrm{NO}_{2}$ group of the inhibitor forms H-bond with Tyr72 and Tyr124 whereas the chlorine atom has weak interaction with Ser293. 


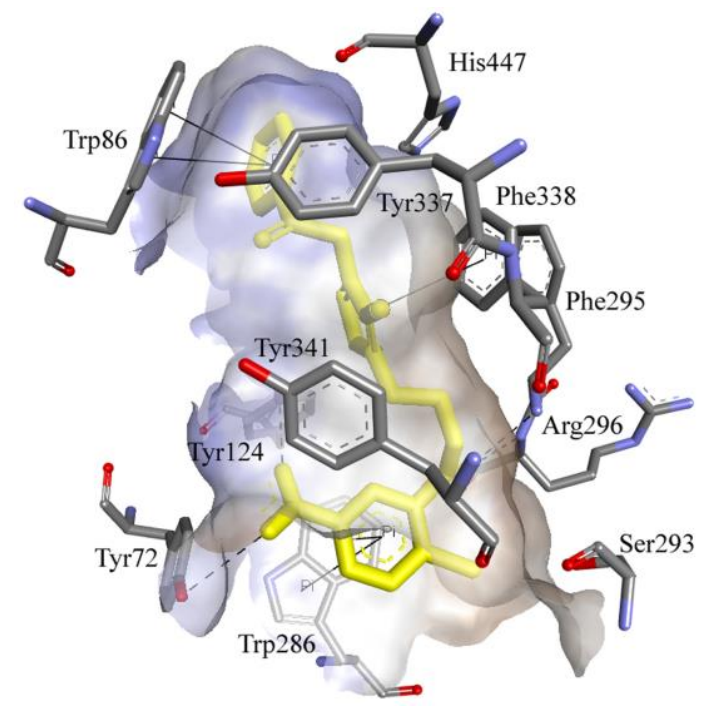

Figure 5. Possible binding mode of compound $\mathbf{1 4}$ at the active site of human AChE.

In case of BChE, compound $\mathbf{2 0}$ occupies the anionic and esterase subsites (Figure 6) that is consistent with the mechanism of competitive inhibition. The binding energy was calculated to be $-8.25 \mathrm{kcal} / \mathrm{mol}$. $N$-Phenacyl fragment is located between Trp82 and His438, while carbonyl atom of oxygen forms hydrogen bonds with Trp82, Trp430, and Tyr440. The thiazolium ring of the inhibitor is close to Tyr332. One phenyl ring of the bulky diphenylmethyl fragment is located in esterase subsite and surrounded by Trp231, Leu286, Phe329, Phe398, and His438. Another phenyl ring is located close to Gly116 and Gly117 of the oxyanion hole. The hydrophobic, van der Waals, and electrostatic interactions can be important for stabilization of this enzymeinhibitor complex.

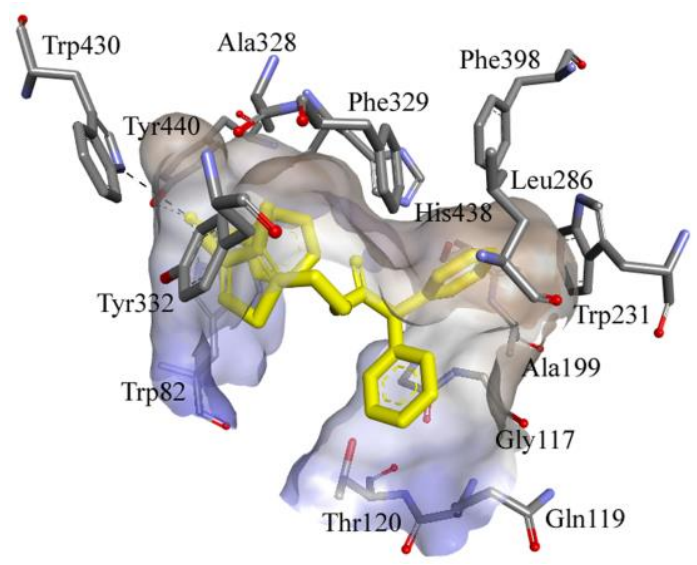

Figure 6. Possible binding mode of compound $\mathbf{1 7}$ at the active site of human BChE.

This study showed that 5-substituted $\mathrm{N}$ phenacylthiazolium derivatives 6-9, 15, and 17 can selectively inhibit BChE as compared with AChE. The differences between the inhibition profiles can be interpreted on a structural basis. The catalytic sites of both enzymes are located at the bottom of the gorge on the depth of about $20 \AA$ and are surrounded at the exit by amino acid residues of peripheral anionic sites [43, 44]. Some of aromatic amino acid residues at the active site gorge of AChE are replaced by aliphatic ones in BChE [45]. Therefore, the acyl pocket of $\mathrm{BChE}$ is wider which enables to bind of bulky ligands [46] whereas AChE is structurally adapted to acetylcholine. According to this, acyl binding pocket of $\mathrm{BChE}$ accommodates phenyl ring of diphenylmethyl fragment of inhibitor 17 (Figure 6). The aromatic amino acid residues of Tyr72, Tyr124 and $\operatorname{Trp} 286$ at the peripheral anionic site of AChE are represented by Asn68, Gln119 and 
Ala277 in case of BChE, which also promotes the binding of bulky molecules.

\section{Conclusion}

We found that the derivatives 3phenacyl-4-methyl-5-substituted thiazolium salts can inhibit activity of $\mathrm{BChE}$ and $\mathrm{AChE}$ exhibiting micromolar $\mathrm{IC}_{50}$ values. The nature of substituent in position 5 of the thiazolium salts may influence sufficiently their inhibitory potency. Among the compounds tested, the best inhibitor of $\mathrm{BChE}$ with more then 50-fold selectivity over AChE was compound $\mathbf{1 7}$ bearing bulky diphenylmethyl fragment $\left(\mathrm{IC}_{50}=\right.$ $0.14 \mu \mathrm{M})$. Compound 14 with 2-chlor-5nitrophenyl moiety was found to be dual AChE and $\mathrm{BChE}$ inhibitors $\left(\mathrm{IC}_{50}\right.$ of $0.85 \mu \mathrm{M}$ and 1.4 $\mu \mathrm{M}$, respectively). Molecular docking results indicate that inhibitor $\mathbf{1 4}$ in the active site of $\mathrm{AChE}$ and compound $\mathbf{1 7}$ in the active site of BChE are stabilized by hydrogen bonds and hydrophobic interactions. The data obtained suggest that $N$-phenacylthiazolium salt can be promising scaffold for designing inhibitors of the cholinesterases.

\section{Materials and methods}

\subsection{Chemistry}

${ }^{1} \mathrm{H}$ NMR spectra were recorded on a Varian M400 (400 MHz/100 MHz) spectrometer in DMSO-d 6 . 4,5Dimethylthiazole (1) and 4-methyl-5-(2hydroxyethyl)thiazole (3) were commercially available and used after distillation. Compounds 4a-i were prepared by reaction of 5-(2hydroxyethyl)-4-methyl-1,3-thiazole (3) with the appropriate acyl chlorides [36-38] in benzene in the presence of triethylamine. Acyl chlorides were produced by standard methods from corresponding carboxylic acids. Phenacyl bromide and $p$-bromophenacyl bromide were obtained from Sigma-Aldrich. 3-[2-(4Bromophenyl)-2-oxoethyl]-4,5-dimethyl-1,3thiazolium bromide $\mathbf{2}$ was synthesized as described previously [32].

\subsubsection{General procedure for the synthesis of $N$ -} phenacylthiazolium salts 5-17

Synthesis of compounds 5-13, 17. Phenacyl bromide or $p$-bromophenacyl bromide $(5 \mathrm{mmol})$ was added to a solution of $5 \mathrm{mmol}$ of 4-methyl5-substituted thiazole (compounds 4a-f,i) in acetone. The reaction mixture was heated under reflux for 3-5 h. After that, the reaction was left standing at room temperature. The product was treated with acetone and diethyl ether, filtered and recrystallized from methanol-acetonediethyl ether mixture to give compounds 5-13, 17.

Synthesis of compounds 14-16. A mixture of phenacyl bromide or $p$-bromophenacyl bromide (5 mmol) and $5 \mathrm{mmol}$ of 4-methyl-5-substituted thiazole (compounds $\mathbf{4 g , h}$ ) was heated at 100$110{ }^{\circ} \mathrm{C}$ for $1.5-3 \mathrm{~h}$. After that, acetone and diethyl ether were added to wash the solidified product and the mixture left standing at room 
temperature. The product was recrystallized from methanol-acetone or $i$-propanol to give compounds 14-16.

3-[2-(4-bromophenyl)-2-oxoethyl]-4,5-dimethyl1,3-thiazolium bromide (2). Yield of $65 \%$, a white solid, m.p. $\quad{ }^{189-191}{ }^{\circ} \mathrm{C} ; \quad{ }^{1} \mathrm{H}$ NMR (DMSO-d $6,400 \mathrm{MHz}, \delta, \mathrm{ppm}): 9.98$ (s, 1H), $7.99(\mathrm{~d}, 2 \mathrm{H}, J=8.4 \mathrm{~Hz}), 7.88(\mathrm{~d}, 2 \mathrm{H}, J=8.4$ $\mathrm{Hz}), 6.41(\mathrm{~s}, 2 \mathrm{H}), 2.53$ (s, 3H), $2.31(\mathrm{~s}, 3 \mathrm{H})$. Anal. calcd. for $\mathrm{C}_{13} \mathrm{H}_{13} \mathrm{Br}_{2} \mathrm{NOS}$ : C, 39.92; $\mathrm{H}$, 3.35 ; N, 3.58; S, 8.20. Found: C, 39.99; H, 3.44; $\mathrm{N}, 3.59 ; \mathrm{S}, 8.35$.

\section{3[2-(4-bromophenyl)-2-oxoethyl]-5-\{2-}

[(cyclopropylcarbonyl)oxy]ethyl]-4-methyl-1,3thiazolium bromide (5). Yield of $52 \%$, a white solid, m.p. ${ }^{176-178}{ }^{\circ} \mathrm{C} ;{ }^{1} \mathrm{H}$ NMR (DMSO-d 6 , $400 \mathrm{MHz}, \delta, \mathrm{ppm}$ ): 10.03 (s, 1H), 7.99 (d, 2H, $J$ $=8.7 \mathrm{~Hz}), 7.89(\mathrm{~d}, 2 \mathrm{H}, J=8.7 \mathrm{~Hz}), 6.40(\mathrm{~s}, 2 \mathrm{H})$, $4.25(\mathrm{t}, 2 \mathrm{H}, J=5.6 \mathrm{~Hz}), 3.33(\mathrm{t}, 2 \mathrm{H}, J=5.6 \mathrm{~Hz})$, $2.36(\mathrm{~s}, 3 \mathrm{H}), 1.65-1.59(\mathrm{~m}, 1 \mathrm{H}), 0.92-0.82(\mathrm{~m}$, $4 \mathrm{H})$. Anal. calcd. for $\mathrm{C}_{18} \mathrm{H}_{19} \mathrm{Br}_{2} \mathrm{NO}_{3} \mathrm{~S}$ : C, 44.19; H, 3.91; N, 2.86; S, 6.55. Found: C, 44.43; H, 3.93; N, 2.81; S, 6.43 .

\section{5-\{2-[(bicyclo[2.2.1]hept-1-}

ylcarbonyl)oxy] ethyl)-4-methyl-3-(2-oxo-2phenylethyl)-1,3-thiazolium bromide (6). Yield of $56 \%$, a white solid, m.p. $180-182{ }^{\circ} \mathrm{C}$; ${ }^{1} \mathrm{H}$ NMR (DMSO-d $6,400 \mathrm{MHz}, \delta, \mathrm{ppm}$ ): 10.05 (s, 1H), $8.06(\mathrm{~d}, 2 \mathrm{H}, J=7.5 \mathrm{~Hz}), 7.79$ (t, $1 \mathrm{H}, J=$ $7.5 \mathrm{~Hz}), 7.65$ (t, 2H, $J=7.5 \mathrm{~Hz}), 6.44(\mathrm{~s}, 2 \mathrm{H})$, $4.28(\mathrm{t}, 2 \mathrm{H}, J=5.6 \mathrm{~Hz}), 3.33(\mathrm{t}, 2 \mathrm{H}, J=5.6 \mathrm{~Hz})$, $2.36(\mathrm{~s}, 3 \mathrm{H}), 2.27(\mathrm{~s}, 1 \mathrm{H}), 1.82-1.75(\mathrm{~m}, 2 \mathrm{H})$, 1.67-1.62 (m, 2H), 1.50-1.45 (m, 4H), 1.35-1.26 (m, 2H). Anal. calcd. for $\mathrm{C}_{22} \mathrm{H}_{26} \mathrm{BrNO}_{3} \mathrm{~S}: \mathrm{C}$, 56.90; H, 5.64; N, 3.02; S, 6.89. Found: C, 56.94; H, 5.75; N, 3.11; S, 6.95.

5-[2-(benzoyloxy)ethyl]-3-[2-(4-bromophenyl)2-oxoethyl]-4-methyl-1,3-thiazolium bromide (7). Yield of $60 \%$, a white solid, m.p. 190-192 ${ }^{\circ} \mathrm{C}$; ${ }^{1} \mathrm{H}$ NMR (DMSO- $\mathrm{d}_{6}, 400 \mathrm{MHz}, \delta, \mathrm{ppm}$ ): $10.01(\mathrm{~s}, 1 \mathrm{H}), 7.99-7.96(\mathrm{~m}, 4 \mathrm{H}), 7.88(\mathrm{~d}, 2 \mathrm{H}, J$ $=8.4 \mathrm{~Hz}), 7.69(\mathrm{t}, 1 \mathrm{H}, J=7.5 \mathrm{~Hz}), 7.55(\mathrm{t}, 2 \mathrm{H}, J$ $=7.5 \mathrm{~Hz}), 6.38(\mathrm{~s}, 2 \mathrm{H}), 4.52(\mathrm{t}, 2 \mathrm{H}, J=5.6 \mathrm{~Hz})$, $3.48(\mathrm{t}, 2 \mathrm{H}, J=5.6 \mathrm{~Hz}), 2.38$ (s, $3 \mathrm{H})$. Anal. calcd. for $\mathrm{C}_{21} \mathrm{H}_{19} \mathrm{Br}_{2} \mathrm{NO}_{3} \mathrm{~S}: \mathrm{C}, 48.02 ; \mathrm{H}, 3.65 ; \mathrm{N}$, 2.67; S, 6.10. Found: C, 48.37; H, 3.74; N, 2.75; S, 6.52 .

5-[2-(benzoyloxy)ethyl]-4-methyl-3-(2-oxo-2phenylethyl)-1,3-thiazolium bromide (8). Yield of $58 \%$, a white solid, m.p. $180-182{ }^{\circ} \mathrm{C}$; ${ }^{1} \mathrm{H}$ NMR (DMSO-d $6,400 \mathrm{MHz}, \delta, \mathrm{ppm}$ ): 10.06 (s, 1H), $8.06(\mathrm{~d}, 2 \mathrm{H}, J=7.5 \mathrm{~Hz}), 7.99(\mathrm{~d}, 2 \mathrm{H}, J$ $=7.5 \mathrm{~Hz}), 7.78(\mathrm{t}, 1 \mathrm{H}, J=7.5 \mathrm{~Hz}), 7.70-7.63$ $(\mathrm{m}, 3 \mathrm{H}), 7.55(\mathrm{t}, 2 \mathrm{H}, J=7.5 \mathrm{~Hz}), 6.44(\mathrm{~s}, 2 \mathrm{H})$, $4.53(\mathrm{t}, 2 \mathrm{H}, J=5.6 \mathrm{~Hz}), 3.49(\mathrm{t}, 2 \mathrm{H}, J=5.6 \mathrm{~Hz})$, 2.39 (s, $3 \mathrm{H})$. Anal. calcd. for $\mathrm{C}_{21} \mathrm{H}_{20} \mathrm{BrNO}_{3} \mathrm{~S}: \mathrm{C}$, 56.51; H, 4.52; N, 3.14; S, 7.18. Found: C, $56.67 ; \mathrm{H}, 4.43 ; \mathrm{N}, 3.24 ; \mathrm{S}, 7.19$.

5-\{2-[(4-methoxybenzoyl)oxy]ethyl\}-4-methyl-3(2-oxo-2-phenylethyl)-1,3-thiazolium bromide 
(9). Yield of $70 \%$, a white solid, m.p. 199-201

${ }^{\circ} \mathrm{C} ;{ }^{1} \mathrm{H}$ NMR (DMSO-d $6,400 \mathrm{MHz}, \delta, \mathrm{ppm}$ ): 10.05 (s, 1H), 8.06 (d, 2H, J = 7.5 Hz), 7.94 (d, $2 \mathrm{H}, J=9.3 \mathrm{~Hz}), 7.79(\mathrm{t}, 1 \mathrm{H}, J=7.5 \mathrm{~Hz}), 7.65(\mathrm{t}$, $2 \mathrm{H}, J=7.5 \mathrm{~Hz}), 7.06(\mathrm{~d}, 2 \mathrm{H}, J=8.4 \mathrm{~Hz}), 6.43$ $(\mathrm{s}, 2 \mathrm{H}), 4.49(\mathrm{t}, 2 \mathrm{H}, J=5.6 \mathrm{~Hz}), 3.83(\mathrm{~s}, 3 \mathrm{H})$, $3.46(\mathrm{t}, 2 \mathrm{H}, J=5.6 \mathrm{~Hz}), 2.38(\mathrm{~s}, 3 \mathrm{H})$. Anal. calcd. for $\mathrm{C}_{22} \mathrm{H}_{22} \mathrm{BrNO}_{4} \mathrm{~S}$ : C, 55.47; $\mathrm{H}, 4.65 ; \mathrm{N}$, 2.94; S, 6.73. Found: C, 55.69; H, 4.73; N, 2.89; S, 7.07.

3-[2-(4-bromophenyl)-2-oxoethyl]-4-methyl-5\{2-[(4-nitrobenzoyl)oxy]ethyl\}-1,3-thiazolium bromide (10). Yield of $55 \%$, a white solid, m.p. 228-230 ${ }^{\circ} \mathrm{C}$; ${ }^{1} \mathrm{H}$ NMR (DMSO-d $6,400 \mathrm{MHz}, \delta$, ppm): 10.01 (s, 1H), $8.36(\mathrm{~d}, 2 \mathrm{H}, J=8.4 \mathrm{~Hz})$, $8.20(\mathrm{~d}, 2 \mathrm{H}, J=8.4 \mathrm{~Hz}), 7.97(\mathrm{~d}, 2 \mathrm{H}, J=8.4$ $\mathrm{Hz}), 7.88$ (d, 2H, J = 8.4 Hz), 6.37 (s, 2H), 4.58 $(\mathrm{t}, 2 \mathrm{H}, J=5.6 \mathrm{~Hz}), 3.50(\mathrm{t}, 2 \mathrm{H}, J=5.6 \mathrm{~Hz}), 2.38$ (s, 3H). Anal. calcd. for $\mathrm{C}_{21} \mathrm{H}_{18} \mathrm{Br}_{2} \mathrm{~N}_{2} \mathrm{O}_{5} \mathrm{~S}$ : C, 44.23; H, 3.18; N, 4.91; S, 5.63. Found: C, 44.46; H, 3.23; N, 5.04; S, 5.74.

4-methyl-5-\{2-[(4-nitrobenzoyl)oxy]ethyl\}-3-(2oxo-2-phenylethyl)-1,3-thiazolium bromide (11). Yield of $51 \%$, a white solid, m.p. $220-221^{\circ} \mathrm{C}$; ${ }^{1} \mathrm{H}$ NMR (DMSO-d $6,400 \mathrm{MHz}, \delta, \mathrm{ppm}$ ): 10.10 (s, 1H), 8.37 (d, 2H, $J=9.3 \mathrm{~Hz}), 8.20$ (d, 2H, $J$ $=8.4 \mathrm{~Hz}), 8.06(\mathrm{~d}, 2 \mathrm{H}, J=7.5 \mathrm{~Hz}), 7.78(\mathrm{t}, 1 \mathrm{H}$, $J=7.5 \mathrm{~Hz}), 7.65(\mathrm{t}, 2 \mathrm{H}, J=7.5 \mathrm{~Hz}), 6.47(\mathrm{~s}$, 2H), 4.59 (t, 2H, $J=5.6 \mathrm{~Hz}), 3.52$ (t, 2H, $J=5.6$ $\mathrm{Hz}), \quad 2.39$ (s, 3H). Anal. calcd. for
$\mathrm{C}_{21} \mathrm{H}_{19} \mathrm{BrN}_{2} \mathrm{O}_{5} \mathrm{~S}: \mathrm{C}, 51.33 ; \mathrm{H}, 3.90 ; \mathrm{N}, 5.70 ; \mathrm{S}$, 6.53. Found: C, 51.56; H, 3.96; N, 5.71; S, 6.62.

3-[2-(4-bromophenyl)-2-oxoethyl]-4-methyl-5\{2-[(3-nitrobenzoyl)oxy]ethyl\}-1,3-thiazolium bromide (12). Yield of $58 \%$, a white solid, m.p. 204-206 ${ }^{\circ} \mathrm{C} ;{ }^{1} \mathrm{H}$ NMR (DMSO-d $6,400 \mathrm{MHz}, \delta$, ppm): 10.03 (s, 1H), 8.64 (s, 1H), 8.53 (d, 1H, $J$ $=7.5 \mathrm{~Hz}), 8.38(\mathrm{~d}, 1 \mathrm{H}, J=7.5 \mathrm{~Hz}), 7.95(\mathrm{~d}, 2 \mathrm{H}$, $J=8.4 \mathrm{~Hz}), 7.87(\mathrm{t}, 3 \mathrm{H}, J=7.5 \mathrm{~Hz}) 6.39(\mathrm{~s}$, $2 \mathrm{H}), 4.60(\mathrm{t}, 2 \mathrm{H}, J=5.6 \mathrm{~Hz}), 3.52(\mathrm{t}, 2 \mathrm{H}, J=5.6$ $\mathrm{Hz}), \quad 2.39 \quad(\mathrm{~s}, \quad 3 \mathrm{H})$. Anal. calcd. for $\mathrm{C}_{21} \mathrm{H}_{18} \mathrm{Br}_{2} \mathrm{~N}_{2} \mathrm{O}_{5} \mathrm{~S}: \mathrm{C}, 44.23 ; \mathrm{H}, 3.18 ; \mathrm{N}, 4.91 ; \mathrm{S}$, 5.63. Found: C, 44.90; H, 3.12; N, 4.66; S, 5.81.

4-methyl-5-\{2-[(3-nitrobenzoyl)oxy]ethyl\}-3-(2oxo-2-phenylethyl)-1,3-thiazolium bromide (13). Yield of $57 \%$, a white solid, m.p. $187-190{ }^{\circ} \mathrm{C}$; ${ }^{1} \mathrm{H}$ NMR (DMSO-d $6,400 \mathrm{MHz}, \delta, \mathrm{ppm}$ ): 10.06 (s, 1H), $8.64(\mathrm{~s}, 1 \mathrm{H}), 8.53(\mathrm{~d}, 1 \mathrm{H}, J=8.4 \mathrm{~Hz})$, $8.38(\mathrm{~d}, 1 \mathrm{H}, J=7.5 \mathrm{~Hz}), 8.03(\mathrm{~d}, 2 \mathrm{H}, J=7.5$ $\mathrm{Hz}), 7.87$ (t, 1H, $J=7.5 \mathrm{~Hz}), 7.78(\mathrm{t}, 1 \mathrm{H}, J=7.5$ $\mathrm{Hz}), 7.64$ (t, 2H, $J=7.5 \mathrm{~Hz}), 6.43$ (s, 2H), 4.60 $(\mathrm{t}, 2 \mathrm{H}, J=5.6 \mathrm{~Hz}), 3.53(\mathrm{t}, 2 \mathrm{H}, J=5.6 \mathrm{~Hz}), 2.40$ (s, 3H). Anal. calcd. for $\mathrm{C}_{21} \mathrm{H}_{19} \mathrm{BrN}_{2} \mathrm{O}_{5} \mathrm{~S}: \mathrm{C}$, 51.33; H, 3.90; N, 5.70; S, 6.53. Found: C, 51.47; H, 3.98; N, 5.53; S, 6.60.

5-\{2-[(2-chloro-5-nitrobenzoyl)oxy]ethyl $\}-4-$ methyl-3-(2-oxo-2-phenylethyl)-1,3-thiazolium bromide (14). Yield of $65 \%$, a light yellow solid, m.p. ${ }^{177-178}{ }^{\circ} \mathrm{C}$; ${ }^{1} \mathrm{H}$ NMR (DMSO-d 6 , $400 \mathrm{MHz}, \delta, \mathrm{ppm}): 10.16$ (s, 1H), 8.61 (d, 1H, $J$ 
$=2.8 \mathrm{~Hz}), 8.41(\mathrm{dd}, 1 \mathrm{H}, J=9.3,2.8 \mathrm{~Hz}), 8.03$ $(\mathrm{d}, 2 \mathrm{H}, J=7.5 \mathrm{~Hz}), 7.92(\mathrm{~d}, 1 \mathrm{H}, J=8.4, \mathrm{~Hz})$, $7.78(\mathrm{t}, 1 \mathrm{H}, J=7.5 \mathrm{~Hz}), 7.64(\mathrm{t}, 2 \mathrm{H}, J=7.5 \mathrm{~Hz})$, $6.49(\mathrm{~s}, 2 \mathrm{H}), 4.60(\mathrm{t}, 2 \mathrm{H}, J=5.6 \mathrm{~Hz}), 3.52(\mathrm{t}$, $2 \mathrm{H}, J=5.6 \mathrm{~Hz}), 2.39$ (s, 3H). Anal. calcd. for $\mathrm{C}_{21} \mathrm{H}_{18} \mathrm{BrClN}_{2} \mathrm{O}_{5} \mathrm{~S}: \mathrm{C}, 47.97 ; \mathrm{H}, 3.45 ; \mathrm{N}, 5.33$; S, 6.10. Found: C, 48.24; H, 3.54; N, 5.45; S, 6.15 .

3-[2-(4-bromophenyl)-2-oxoethyl]-4-methyl-5\{2-[(4-morpholin-4-yl-3nitrobenzoyl)oxy]ethyl\}-1,3-thiazolium bromide (15). Yield of $40 \%$, a yellow solid, m.p. 175$177{ }^{\circ} \mathrm{C} ;{ }^{1} \mathrm{H}$ NMR (DMSO-d $6,400 \mathrm{MHz}, \delta$, ppm): 10.06 (s, 1H), 8.30 (s, 1H), 8.04 (d, 1H, $J$ $=8.4), 7.97(\mathrm{~d}, 2 \mathrm{H}, J=7.5), 7.87(\mathrm{~d}, 2 \mathrm{H}, J=8.4$ $\mathrm{Hz}), 7.37(\mathrm{~d}, 1 \mathrm{H}, J=8.4 \mathrm{~Hz}), 6.41(\mathrm{~s}, 2 \mathrm{H}), 4.53$ $(\mathrm{t}, 2 \mathrm{H}, J=5.6 \mathrm{~Hz}), 3.70(\mathrm{~s}, 4 \mathrm{H}), 3.48(\mathrm{t}, 2 \mathrm{H}, J=$ $5.6 \mathrm{~Hz}), 3.16$ (s, 4H), 2.38 (s, 3H). Anal. calcd. for $\mathrm{C}_{25} \mathrm{H}_{25} \mathrm{Br}_{2} \mathrm{~N}_{3} \mathrm{O}_{6} \mathrm{~S}$ : C, 45.82; H, 3.85; N, 6.41; S, 4.89. Found: C, 45.93; H, 3.89; N, 6.38; S, 4.78.

4-methyl-5-\{2-[(4-morpholin-4-yl-3nitrobenzoyl)oxy] ethyl)-3-(2-oxo-2phenylethyl)-1,3-thiazolium bromide (16). Yield of $43 \%$, a yellow solid, m.p. $178-180{ }^{\circ} \mathrm{C}$; ${ }^{1} \mathrm{H}_{\mathrm{NMR}}$ (DMSO-d $6,400 \mathrm{MHz}, \delta, \mathrm{ppm}$ ): 10.06 (s, 1H), $8.31(\mathrm{~s}, 1 \mathrm{H}), 8.04$ (d, 3H, $J=7.5 \mathrm{~Hz})$, $7.78(\mathrm{t}, 1 \mathrm{H}, J=7.5 \mathrm{~Hz}), 7.65(\mathrm{t}, 2 \mathrm{H}, J=7.5 \mathrm{~Hz})$ $7.38(\mathrm{~d}, 1 \mathrm{H}, J=9.3 \mathrm{~Hz}) 6.42(\mathrm{~s}, 2 \mathrm{H}), 4.53(\mathrm{t}$, $2 \mathrm{H}, J=5.6 \mathrm{~Hz}), 3.70(\mathrm{t}, 4 \mathrm{H}, J=4.7 \mathrm{~Hz}), 3.49(\mathrm{t}$, $2 \mathrm{H}, J=5.6 \mathrm{~Hz}), 3.16(\mathrm{t}, 4 \mathrm{H}, J=4.7 \mathrm{~Hz}), 2.38$ (s, 3H). Anal. calcd. for $\mathrm{C}_{25} \mathrm{H}_{26} \mathrm{BrN}_{3} \mathrm{O}_{6} \mathrm{~S}$ : $\mathrm{C}$, 52.09; H, 4.55; N, 7.29; S, 5.56. Found: C, $51.98 ; \mathrm{H}, 4.51 ; \mathrm{N}, 7.21 ; \mathrm{S}, 5.52$.

5-\{2-[(diphenylacetyl)oxy]ethyl $\}-4-m e t h y l-3-(2-$ oxo-2-phenylethyl)-1,3-thiazolium bromide (17). Yield of $70 \%$, a white solid, m.p. $165-167{ }^{\circ} \mathrm{C}$; ${ }^{1} \mathrm{H}$ NMR (DMSO-d $6,400 \mathrm{MHz}, \delta, \mathrm{ppm}$ ): 9.97 $(\mathrm{s}, 1 \mathrm{H}), 8.08(\mathrm{~d}, 2 \mathrm{H}, J=7.5 \mathrm{~Hz}), 7.80(\mathrm{t}, 1 \mathrm{H}, J=$ $7.5 \mathrm{~Hz}), 7.67(\mathrm{t}, 2 \mathrm{H}, J=7.5 \mathrm{~Hz}), 7.35-7.24(\mathrm{~m}$, $10 \mathrm{H}), 6.35(\mathrm{~s}, 2 \mathrm{H}), 5.19(\mathrm{~s}, 1 \mathrm{H}), 4.36(\mathrm{t}, 2 \mathrm{H}, J=$ $6.0 \mathrm{~Hz}), 3.31(\mathrm{t}, 2 \mathrm{H}, J=6.0 \mathrm{~Hz}), 2.23(\mathrm{~s}, 3 \mathrm{H})$. Anal. calcd. for $\mathrm{C}_{28} \mathrm{H}_{26} \mathrm{BrNO}_{3} \mathrm{~S}: \mathrm{C}, 62.69 ; \mathrm{H}$, 4.88; N, 2.61; S, 5.98. Found: C, 62.83; H, 4.95; $\mathrm{N}, 2.70 ; \mathrm{S}, 6.06$.

4.2. In vitro study of acetylcholinesterase and butyrylcholinesterase inhibition

Acetylcholinesterase from E. electricus, butyrylcholinesterase from equine serum and Ellman's reagent (DTNB) were purchased from Sigma-Aldrich. S-Acetylthiocholine iodide and S-butyrylthiocholine iodide from Sigma-Aldrich and Fluka, respectively, were used as substrates. The inhibitory activities of compounds were determined by modified Ellman's method [47]. Spectrophotometric study was performed at a wavelength of $412 \mathrm{~nm}$.

Reaction mixture was consisted of 25 $\mathrm{mM}$ phosphate buffer ( $\mathrm{pH}$ 7.48), $0.1 \mathrm{mM} \mathrm{S}$ acetylthiocholine iodide, $1 \mathrm{mM}$ DTNB, $1 \%$ dimethyl sulfoxide (DMSO), water, and inhibitor. Before used in the experiments, the 
tested compounds 2 and 5-17 were dissolved in DMSO and then were diluted with water to the required concentration. The prepared mixture was incubated during 5 minutes at $25^{\circ} \mathrm{C}$ and substrate hydrolysis was started by adding the enzyme. The inhibitory activity of thiazolium salts toward BChE was study in similar assay conditions with the concentration of Sbutyrylthiocholine iodide of $0.5 \mathrm{mM}$.

The Hill coefficients (values \pm standard error) for compounds 14 and 17 were calculated from dose-dependent inhibition curves (Figures 1 and 2) with using of four parameters equation. The values of $\mathrm{IC}_{50}$ (Table 1) were the concentration of inhibitor which reduces enzyme activity by $50 \%$. The kinetic data of enzymatic transformation of S-acetylthiocholine iodide and S-butyrylthiocholine iodide in the absence and presence of compounds $\mathbf{1 6}$ and $\mathbf{2 0}$ were analyzed from Lineweaver-Burk plots (Figures 3 and 4). The molar extinction coefficient of 5-thio-2-nitrobenzoate $\left(\mathrm{TNB}^{2-}\right)$ of $14150 \mathrm{M}^{-1} \mathrm{~cm}^{-1}$ was used [48] for calculation.

Selectivity index ( $\mathrm{IC}_{50}$ of $\mathrm{AChE} / \mathrm{IC}_{50}$ of $\mathrm{BChE}$ ) was estimated using the recalculated $\mathrm{IC}_{50}$ values [49] for $\mathrm{BChE}$ at $0.1 \mathrm{mM}$ substrate concentration assuming competitive inhibition.

\subsection{Molecular docking}

Molecular docking was performed by using Autodock 4.2 program. The compound 14 was docked to the active site of A chain of human AChE (PDB code 4EY7 [50]). The compound 17 was docked to the active site gorge of human BChE (PDB code 4BDS [51]). Before starting the docking calculations, ligands and water molecules were removed from initial PDB crystals. The structures of inhibitors were optimized by AM1 semi-empirical quantum mechanical method in program MOPAC. MGLTools was used to prepare the docking files. The most probable binding modes were predicted by using the Lamarckian genetic algorithm (LGA) method.

\section{Reference}

[1] Giacobini E. Cholinesterase inhibitors: new roles and therapeutic alternatives. Pharmacol. Res. 2004; 50:433-440.

[2] Greig NH, Utsuki T, Yu Q, Zhu X, Holloway HW, Perry T, Lee B, Ingram DK, Lahiri DK. A new therapeutic target in Alzheimer's disease treatment: attention to butyrylcholinesterase. Curr. Med. Res. Opin. 2001;17(3):159-165.

[3] Perry EK, McKeith I, Thompson P, Marshall E, Kerwin J, Jabeen S, Edwardson JA, Ince P, Blessed G, Irving D, Perry RH. Topography, extent, and clinical relevance of neurochemical deficits in dementia of Lewy body type, Parkinson's disease, and Alzheimer's disease. Ann. N. Y. Acad. Sci. 1991;640:197-202.

[4] Perry EK, Gibson PH, Blessed G, Perry RH, Tomlinson B.E. Neurotransmitter enzyme abnormalities in senile dementia: Choline acetyltransferase and glutamic acid decarboxylase activities in necropsy brain tissue. J. Neurol. Sci. 1977;34(2):247-265.

[5] Francis P, Palmer A, Snape M, Wilcock G. The cholinergic hypothesis of Alzheimer's disease: a review of progress. J. Neurol. Neurosurg. Psychiatry. 1999;66(2):137-147.

[6] Whitehouse PJ, Price DL, Struble RG, Clark AW, Coyle JT, Delon MR. Alzheimer's disease and senile 
dementia: loss of neurons in the basal forebrain. Science. 1982;215(4537):1237-1239.

[7] Ballard CG, Greig NH, Guillozet-Bongaarts AL, Enz A, Darvesh S. Cholinesterases: roles in the brain during health and disease. Curr. Alzheimer Res. 2005;2(3):307-318.

[8] Cummings JL. Cholinesterase inhibitors: a new class of psychotropic compounds. Am. J. Psychiatr. 2000;157(1):4-15.

[9] Bergman J, Lerner V. Successful use of donepezil for the treatment of psychotic symptoms in patients with Parkinson's disease. Clin. Neuropharmacol. 2002;25(2):107-110.

[10] Rojas-Fernandez CH. Successful use of donepezil for the treatment of dementia with Lewy bodies. Ann. Pharmacother. 2001;35(2):202-205.

[11] Aarsland D, Mosimann UP, McKeith IG. Role of cholinesterases inhibitors in Parkinson's disease and dementia with Lewy bodies. J. Geriatr. Psychiatry. Neurol. 2004;12(3):164-171.

[12] Radic Z, Pickering NA, Vellom DC, Camp $\mathrm{S}$, Taylor P. Three distinct domains in the cholinesterase molecule confer selectivity for acetyl- and butyrylcholinesterase inhibitors. Biochemistry. 1993;32(45):12074-12084.

[13] Schwarz M, Glick D, Loewenstein Y, Soreq H. Engineering of human cholinesterases explains and predicts diverse consequences of administration of various drugs and poisons. Pharmacol. Ther. 1995;67(2):283-322.

[14] Duysen EG, Stribley JA, Fry DL, Hinrichs $\mathrm{SH}$, Lockridge O. Rescue of the acetylcholinesterase knockout mouse by feeding a liquid diet; phenotype of the adult acetylcholinesterase deficient mouse. Brain Res. Dev. Brain Res. 2002;137:43-54.

[15] Lockridge O. Review of human butyrylcholinesterase structure, function, genetic variants, history of use in the clinic, and potential therapeutic uses. Pharmacol. Ther. 2015;148:34-46.
[16] Guillozet AL, Mesulam MM, Smiley JF, Mash DC. Butyrylcholinesterase in the life cycle of amyloid plaques. Ann. Neurol. 1997;42:909-918.

[17] Perry EK, Tomlinson BE, Blessed G, Bergmann K, Gibson PH, Perry RH. Correlation of cholinergic abnormalities with senile plaques and mental test scores in senile dementia. Br. Med. J. 1978;2:14571459.

[18] Perry EK, Perry RH, Blessed G, Tomlinson BE. Changes in brain cholinesterases in senile dementia of Alzheimer type. Neuropathol. Appl. Neurobiol. 1978;4(4):273-277.

[19] Yurttas L, Kaplancıkli ZA, Özkay Y. Design, synthesis and evaluation of new thiazolepiperazines as acetylcholinesterase inhibitors. J. Enzyme Inhib. Med. Chem. 2013;28(5):1040-1047.

[20] D’Ascenzio M, Chimenti P, Gidaro MC, De Monte C, De Vita D, Granese A, Scipione L, Di Santo R, Costa G, Alcaro S, Yanez M, Carradori S. (Thiazol-2-yl) hydrazone derivatives from acetylpyridines as dual inhibitors of MAO and AChE: synthesis, biological evaluation and molecular modeling studies. J. Enzyme Inhib. Med. Chem. 2015;30(6):908-919.

[21] Sun ZQ, Tu LX, Zhuo FJ, Liu SX. Design and discovery of Novel Thiazoleacetamide derivatives as anticholinesterase agent for possible role in the management of Alzheimer's. Bioorg. Med. Chem. Lett. 2016;26(3):747-750.

[22] Matsunaga Y, Tanaka T, Yoshinaga K, Ueki S, Hori Y, Eta R, Kawabata Y, Yoshii K, Yoshida K, Matsumura T, Furuta S, Takei M, Tack J, Itoh Z. Acotiamide hydrochloride (Z-338), a new selective acetylcholinesterase inhibitor, enhances gastric motility without prolonging QT interval in dogs: comparison with cisapride, itopride, and mosapride. J. Pharmacol. Exp. Ther. 2011;336(3):791-800.

[23] Mohsen UA, Kaplancikli ZA, Özkay Y, Yurttaş L. Synthesis and evaluation of antiacetylcholinesterase activity of some benzothiazole based 
new piperazine-dithiocarbamate derivatives. Drug Res. 2015;65:176-183.

[24] Pejchal V, Stepankova S, Pejchalova M, Kralovec K, Havelek R, Ruzickova Z, Ajani H, Lo R, Lepsik M. Synthesis, structural characterization, docking, lipophilicity and cytotoxicity of 1-[(1R)-1-(6-fluoro-1,3benzothiazol-2-yl)ethyl]-3-alkyl carbamates, novel acetylcholinesterase and butyrylcholinesterase pseudoirreversible inhibitors. Bioorg. Med. Chem. 2016;24(7):1560-1572.

[25] Zhi H, Chen L, Zhang L, Liu S, Wan DCC, Lin H, Hu C. Design, synthesis, and biological evaluation of $5 \mathrm{H}$-thiazolo[3,2-a]pyrimidine derivatives as a new type of acetylcholinesterase inhibitors. Arkivoc. 2008;13:266277.

[26] Liu S, Shang R, Shi L, Wan DCC, Lin H. Synthesis and biological evaluation of $7 \mathrm{H}$-thiazolo[3,2-b]1,2,4-triazin-7-one derivatives as dual binding site acetylcholinesterase inhibitors. Eur. J. Med. Chem. 2014;81:237-244.

[27] Liu S, Shang R, Shi L, Zhou R, Wan DCC. Design, synthesis, and evaluation of $7 H$-thiazolo[3,2-b]1,2,4-triazin-7-one derivatives as dual binding site acetylcholinesterase inhibitors. Chem. Biol. Druq. Des. 2014;84(2):169-178.

[28] Stenlake JB, Dhar NC, Henderson CF, Maehr RB, Scharver J, Wastila WB, Midgley JM. Neuromuscular blocking agents. Approaches to shortacting compounds 2. Bis-thiazolium salts Eur. J. Med. Chem. 1993;28(5):415-418.

[29] Romanenko AV, Vovk AI, Shatursky OYa. Effects of thiazole analogues of vitamin B1 on neuromuscular transmission and $\alpha$-latrotoxin-induced transmitter release in skeletal muscles. Neurophysiologia. 1995;27:291-296.

[30] Booth AA, Khalifah RG, Hudson BG. Thiamine pyrophosphate and pyridoxamine inhibit the formation of antigenic advanced glycation end-products: comparison with aminoguanidine. Biochem. Biophys. Res. Commun. 1996;220:113-119.
[31] Vasan S, Zhang X, Zhang X, Kapurniotu A, Bernhagen J, Teichberg S, Basgen J, Wagle D, Shih D, Terlecky I, Bucala R, Cerami A, Egan J, Ulrich P. An agent cleaving glucose-derived protein crosslinks in vitro and in vivo. Nature. 1996;382(6588):275-278.

[32] Cerami A, Ulrich PC, Wagle DR, Hwang SB, Vasan S, Egan JJ, inventor; The Picower Institute for Medical Research, Alteon Inc., assignee; Preventing and reversing advanced glycosylation endproducts. United States patent 5656261. 1997 Aug 12.

[33] Abdoulaye Bâ. Metabolic and structural role of thiamine in nervous tissues. Cell. Mol. Neurobiol. 2008;28:923-931.

[34] Gibson GE, Hirsch JA, Cirio RT, Jordan BD, Fonzetti P, Elder J. Abnormal thiamine-dependent processes in Alzheimer's Disease. Lessons from diabetes. Mol. Cell. Neurosci. 2013;55:17-25.

[35] Alspach JD, Ingraham LL. Inhibition of acetylcholinesterase by thiamine. A structure-function study. J. Med. Chem. 1977;20(1):161-164.

[36] Buchman ER, Williams RR, Keresztesy JC. Studies of crystalline Vitamin B1. 1 X. Sulfite cleavage. III. Chemistry of the basic product. J. Am. Chem. Soc. 1935;57(10):1849-1851.

[37] Sano T. Vergleich der Wirksamkeit der verschiedenen Aneurinester von organischen Sauren. Bull.Chem. Soc. Jpn. 1944;19(11):185-205.

[38] Matsukawa T, Yurugi S. Studies on vitamin- $B_{1}$ and its related compounds 13. Syntheses vitamin-B ${ }_{1}$-esters. Yakugaku Zasshi (J. Pharm. Soc. Jpn.), $1951 ; 71(2) 69-72$.

[39] Krupka RM, Laidler KJ. Molecular mechanisms for hydrolytic enzyme action. I. Apparent non-competitive inhibition, with special reference to acetylcholinesterase. J. Am. Chem. Soc. 1961;83(6):14451447.

[40] Rosenberry TL, Bernhard SA. Catalysis by acetylcholinesterase. Synergistic effects of inhibitors during the hydrolysis of acetic acid esters. Biochemistry. 1972;11(23):4308-4321. 
[41] Nochi S, Asakawa N, Sato T. Kinetic study on the inhibition of acetylcholinesterase by 1-benzyl-4((5,6-dimethoxy-1-indanon)-2-yl)methylpiperidine hydrochloride (E2020). Biol. Pharm. Bull. 1995;18(8):1145-1147.

[42] Kwon YE, Park JY, No KT, Shin JH, Lee SK, Eun JS, Yang JH, Shin TY, Kim DK, Chae BS, Leem JY, Kim KH. Synthesis, in vitro assay, and molecular modeling of new piperidine derivatives having dual inhibitory potency against acetylcholinesterase and $A \beta_{1-42}$ aggregation for Alzheimer's disease therapeutics. Bioorg. Med. Chem. 2007;15(20):6596-6607.

[43] Sussman JL, Harel M, Frolow F, Oefner C, Goldman A, Toker L, Silman I. Atomic structure of acetylcholinesterase from Torpedo californica: a prototypic acetylcholine-binding protein. Science. 1991;253(5022):872-879.

[44] Nicolet Y, Lockridge O, Masson P, Fontecilla-Camps JC, Nachon F. Crystal structure of human butyrylcholinesterase and of its complexes with substrate and products. J. Biol. Chem. 2003;278(42):41141-41147.

[45] Cokugras AN. Butyrylcholinesterase: structure and physiological importance. Turk. J. Biochem. 2003;28(2):54-61.

[46] Zhan CG, Zheng F, Landry DW. Fundamental reaction mechanism for cocaine hydrolysis in human butyrylcholinesterase. J. Am. Chem. Soc. 2003;125(9):2462-2474.

[47] Ellman GL, Courtney KD, Andres VJr. Featherstone RM. A new and rapid colorimetric determination of acetylcholinesterase activity. Biochem. Pharmacol. 1961;7:88-95.

[48] Eyer P, Worek F, Kiderlen D, Sinko G, Stuglin A, Simeon-Rudolf V, Reiner E. Molar absorption coefficients for the reduced Ellman reagent: reassessment. Anal. Biochem. 2003;312(2):224-227.

[49] Yung-Chi C, Prusoff WH. Relationship between the inhibition constant $\left(K_{i}\right)$ and the concentration of inhibitor which causes 50 per cent inhibition $\left(I_{50}\right)$ of an enzymatic reaction. Biochem. Pharmacol. 1973;22(23):3099-3108.

[50] Cheung J, Rudolph MJ, Burshteyn F, Cassidy MS, Gary EN, Love J, Franklin MC, Height JJ. Structures of human acetylcholinesterase in complex with pharmacologically important ligands. J. Med. Chem. 2012;55(22):10282-10286.

[51] Nachon F, Carletti E, Ronco C, Trovaslet M, Nicolet Y, Jean L, Renard PY. Crystal structures of human cholinesterases in complex with huprine $\mathrm{W}$ and tacrine: elements of specificity for anti-Alzheimer's drugs targeting acetyl-and butyryl-cholinesterase. Biochem. J. 2013;453:393-399. 